\title{
'Sick cell' hyponatraemia and gastrointestinal electrolyte loss
}

\author{
R. R. GHOSE \\ F.R.C.P.Ed., M.R.C.P. \\ Singleton Hospital, Swansea
}

\begin{abstract}
Summary
A patient with protracted vomiting was noted to have hyponatraemia and hypokalaemia on admission. Isotope dilution studies before treatment revealed profound body depletion of sodium, potassium and water. Treatment with potassium chloride tablets produced a simultaneous rise in serum sodium and potassium concentration without change in urine volume or osmolality, or body weight.

Potassium depletion appears to have contributed to the mechanism of hyponatraemia in this situation, and that replacement of potassium corrected hyponatraemia by effectively re-distributing solute and water across the cell membrane, so that sodium ions which had entered intra-cellular fluid during electrolyte depletion, subsequently returned to extracellular fluid after treatment.
\end{abstract}

\section{Introduction}

Complex electrolyte disturbance with prolonged recurrent vomiting may be associated with hyponatraemia. The mechanism is uncertain (Leaf, 1962) but 2 factors are likely. Firstly, sodium deficiency and contraction of extra-cellular fluid (ECF) volume stimulates release of anti-diuretic hormone (ADH). Secondly, impairment of the capacity to excrete a water load promotes water retention and dilution of ECF sodium. This defect in urinary diluting ability is determined by chloride depletion and diminished filtered chloride load, with enhanced proximal tubule chloride and sodium reabsorption, and reduced chloride delivery to the thick ascending limb of the loop of Henle. Active chloride reabsorption at this diluting site, which is impermeable to water, results in the formation of hypotonic urine (Burg, 1976).

When potassium depletion accompanies sodium chloride depletion, renal concentrating ability and water transport across the distal nephron is impaired Relman and Schwartz (1958). This counteracts the effect of volume-mediated ADH activity. Moreover, thirst is enhanced, and exaggerated water ingestion may be followed by delayed water excretion.

In an ambulant patient with combined sodium and potassium deficiency who was treated initially with potassium chloride, it was observed that chloride administration did not improve water excretion as judged by urine volume or osmolality, or body weight. Yet serum sodium concentration promptly rose, suggesting that a third factor, potassium deficiency, contributed to the production of hyponatraemia. This conforms with the 'sick cell' hypothesis (Editorial, 1974), in which hyponatraemia is said to result from movement of ECF sodium into intra-cellular fluid (ICF) in exchange for intracellular potassium. Evidence supporting this hypothesis includes studies on a variety of miscellaneous diseases, but not mixed electrolyte deficiencies (Flear and Singh, 1973).

\section{Methods}

Serum and urine electrolyte concentrations were measured by flame photometry and chloride-meter, and osmolality by Fiske osmometer. Total exchangeable sodium, and potassium, and total body water were estimated by isotope dilution using ${ }^{24} \mathrm{Na},{ }^{42} \mathrm{~K}$ and titrated $\mathrm{H}_{2} \mathrm{O}$, equilibrating over $24 \mathrm{hr}$ (Belcher and Vetter, 1971).

\section{Case report}

A previously healthy 21-year-old female experienced recurrent bouts of painless vomiting with anorexia for 6 weeks. During this period she vomited 6 times/day, with copious volumes for the latter 3 weeks when weakness supervened. Pregnancy was not responsible. Vomiting was not self-induced or accompanied by drug or diuretic abuse or purgation. General condition was satisfactory and the patient remained ambulant. No physical signs were present. BP was $130 / 80 \mathrm{mmHg}$.

\section{Investigations}

Serum osmolality $241 \mathrm{mosmol} / \mathrm{kg}$; sodium 119 $\mathrm{mmol} / \mathrm{l}$; potassium $1.4 \mathrm{mmol} / \mathrm{l}$; chloride $62 \mathrm{mmol} / \mathrm{l}$; urea $4.7 \mathrm{mmol} / 1$; recumbent plasma renin activity $25.4 \mathrm{ng} / \mathrm{ml} / \mathrm{hr} ; \mathrm{pH} 7.51 ; P_{\mathrm{CO}_{2}} 33.1 \mathrm{mmHg}$; base excess $+4.4 \mathrm{mmol} / \mathrm{l}$, cortisol $565 \mathrm{ng} / \mathrm{ml}$, glucose 6.2 $\mathrm{mmol} / 1$, calcium $2.55 \mathrm{mmol} / 1$.

Urine excretion: volume $1000 \mathrm{ml} / 24 \mathrm{hr}$, sodium 
$2.0 \mathrm{mmol} / 24 \mathrm{hr}$, potassium $1.0 \mathrm{mmol} / 24 \mathrm{hr}$, chloride $0 \mathrm{mmol} / 24 \mathrm{hr}$, osmolality $186 \mathrm{mosmol} / \mathrm{kg}$.

Total exchangeable electrolytes (Skrabal, Arnot and Joplin, 1973); sodium $27.6 \mathrm{mmol} / \mathrm{kg}$ (normal $38.1 \mathrm{mmol} / \mathrm{kg}$ ), potassium $10.4 \mathrm{mmol} / \mathrm{kg}$ (normal $39.8 \mathrm{mmol} / \mathrm{kg}$ ), total body water 28.5 litres (normal $28 \cdot 2$ litres).

Maximum urine osmolality after $12 \mathrm{hr}$ water deprivation: $243 \mathrm{mosmol} / \mathrm{kg}$ (when repeated 2 months later this figure was $1153 \mathrm{mosmol} / \mathrm{kg}$ ).

Chest and plain X-rays of abdomen were normal. Barium meal and cholecystogram normal.

\section{Clinical course}

Vomiting stopped following admission to the medical ward. The patient consumed the normal ward diet in which sodium content was approximately $60 \mathrm{mmol} /$ day. Water ingestion remained at the same level throughout the ward stay. The effect of potassium chloride (Slow-K tablets, $104 \mathrm{mmol} /$ day) on serum sodium and potassium concentrations is illustrated in Fig. 1.

The patient quickly regained vigour and her appetite subsequently improved.

Over the following year, bouts of vomiting occurred occasionally for which no physical cause was found. Serum electrolyte concentrations remained within normal limits.

\section{Discussion}

The validity of the 'sick cell' concept for producing hyponatraemia has been disputed (Leaf, 1974). In the present case hyponatraemia was probably due to more than one factor and resulted from sustained gastrointestinal losses of sodium, potassium and chloride, uncompensated for by dietary intake or renal conservation. A simultaneous rise in serum sodium and potassium concentrations during potassium chloride therapy revealed the importance of underlying potassium depletion in the causation of this form of hyponatraemia. Two variables which determine serum sodium concentration (Edelman et al., 1958), namely total body sodium and total body potassium, were reduced with the effect that there was relative dilution of residual ECF and ICF solute. The third variable, total body water, was normal presumably because water ingestion had been maintained. Redistribution of solutes across the cell membrane related to external losses of sodium potassium, with water passively equilibrating in concert with solute movements so that osmolality of ECF and ICF $\frac{\mathbb{Q}}{2}$
remained the same.

Severe potassium depletion interferes with energy $c$ metabolism. The ratio of ECF to ICF potassium $\overrightarrow{\vec{F}}$ concentration, on which cell membrane potential depends, declines with the degree of potassium $\frac{\mathrm{C}}{0}$ depletion (Patrick and Hilton, 1979). Performance of $\frac{\overline{\bar{p}}}{\mathrm{~s}}$ the sodium/potassium 'pump' within the cell mem- $\widehat{\Phi}$ brane, which requires metabolic energy for active $\stackrel{\varrho}{v}$ transport, is reduced. Cellular extrusion of sodium ${ }^{\infty}$ and retention of potassium by the 'pump', which $\overrightarrow{0}$ normally controls cell volume, is consequently impaired. Potassium replacement restores cell mem- $\omega$ brane potential and regenerates the sodium/potassiumo 'pump', effectively mobilizing sodium from the 'sick cell' as shown by a rise in serum sodium concentration in parallel with serum potassium? concentration.

\section{Acknowledgments}

The author is grateful to the Medical Physics Department음 for co-operation with metabolic isotope studies, to theBiochemistry Department, to the Medical Ward Sister forc nursing care, and to Mrs Penhallurick for preparing the typescript.

\section{References}

BelCher, E.H. \& VeTter, H. (1971) Radioisotopes in Mediog Diagnosis, p. 258. Butterworths, London, etc.

BURG, M.B. (1976) Renal chloride transport and diuretio Circulation, 53 (4), 587.

Edelman, I.S., Liebman, J., O'Meara, M.P. \& Berkenfeld, L.W. (1958) Inter-relation between serum sodium con-O centration, serum osmolality and total exchangeable sodium, total exchangeable potassium and total bodyD water. Journal of Clinical Investigation, 37, 1236.

EDITORIAL (1974) Sick cells-hyponatraemia. Lancet $\overrightarrow{\widehat{\sigma}}$ i, 342.

Flear, C.T. \& Singh, C.M. (1973) Hyponatraemia and sick cells. British Journal of Anaesthesia, 45, 976.

LEAF, A. (1974) Hyponatraemia (Correspondence). Lancet: i, 1119.

LEAF, A. (1962) The clinical and physiologic significance of the serum sodium concentration. New England Journato of Medicine, 267, 24.

Patrick, J. \& Hilton, P.J. (1979) Editorial Review: Characterization of sodium-transport disorders in disease:? different effects upon sodium and potassium of changes in the sodium pump and in membrane permeability.윽 Clinical Science, 57, 289.

Relman, A.S. \& Schwartz, W.B. (1958) The kidney in potassium depletion. American Journal of Medicine, 24, 764.

Skrabal, F., Arnot, R.N. \& Joplin, G.F. (1973) Equations for the prediction of normal values for exchangeable $N$ sodium, exchangeable potassium, extracellular fluiof volume, and total body water. British Medical Journal, 2, 37. 